\title{
段階的手順による鋼構造高 層フレームの弾塑性設計法
}

AN ELASTIC AND PLASTIC
DESIGN METHOD OF
MULTI-STORY PLANAR STEEL
FRAMES ON THE
STEP-BY-STEP PROCEDURE

中村雄治 $-* 1$
大上元一 $* 2$
松尾 彰 -33
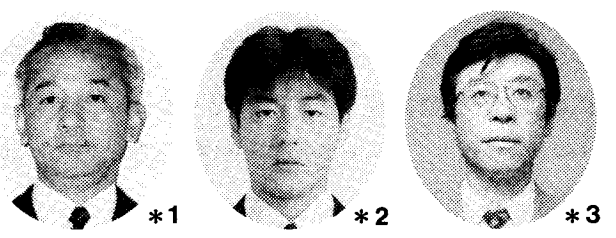

キーワード

鋼構造, 高層平面フレーム, 弾塑性設計法, 剛性設計法

\section{1 はじめに}

構造設計者が中高層建築物の構造計画を行う際、いろいろな試 行錯誤の過程を繰り返しながら計画を具現化していくが、その際、 最適化手法を用いた設計アルゴリズムを用いることは構造設計者 にとって有効な手段となる。現行の建築基準法のルート 3 に準拠 して設計する場合には、一次設計（許容応力度設計）上二次設計 （保有耐力設計）の両方を同時に満足する必要があり、対象構造 物が高層になる程計算時間の面で非効率的になる。そこで、高首 フレームの設計を塑性設計、弾性応力設計、剛性設計の 3 段階に 分けて逐次的に行う方法が実用的亡考えられ、それを用いること によりパラメトリックスタデを容易に行うことができ、基本設 計段階で設計対象の建築構造物の特性をいろいろ検討することが できる。例えば、設計クライテリアにある程度の余力を持たせる ことにより鋼材全重量がどの程度増加するのだろうかとか、最適 な柱間隔はいくらかとか、柱はり各々の最適な使用鋼種は何かと いった基本設計段階で必要な設計のチェックを容易に行うことが できる。そのように基本設計段階で構造設計者の有用なツールと なる設計法として、本報では次のような段階的手順による弾塑性 設計法を提案する。まず、二次設計用の荷重に対する保有耐力設 計に対して、下界定理に基づいた塑性設計法に線形計画法を適用 して部材断面を求める。そして、それらの部材断面を用いて、一 次設計レベルの荷重に対する弾性解析を行って、部材応力度が許

\section{Yuji NAKAMURA \\ Genichi DAIJYOU \\ Akira MATSUO}

In this paper, an elastic and plastic design method of multi-story planar frames on the step-by-step procedure is presented. It contains the optimum plastic design method based on the lower bound theorem and using the linear programming. After the plastic design method is completed, the design proceeds to the elastic analysis for the structure designed by the plastic design method and the member sizes are modified if necessary. And lastly, the deflection control design is taken into consideration, using the Lagrange multiplier approach as the optimum design technique.

\section{Keywords :}

Steel structure, Multi-story planar frames, Elastic and plastic design method, Deflection control design method

容応力度以内に保持されていることを確認し、越えていれば断面

を修正し、次に㴊性設計の検討として各首の弹性層間変位を調へ る。ここで、この岡性設計としてラグランジェ乗数法を適用して 各柱、はりの剛性付加量を求めて部材断面を修正する。そして最 後にここで提案した段階的手順に基づく弾塑性設計法と弾塑性制 約条件を同時に考慮した最適弹塑性設計法による設計解の鉿材重 量と比較し、両者の間にそれほど差のないことを示す。

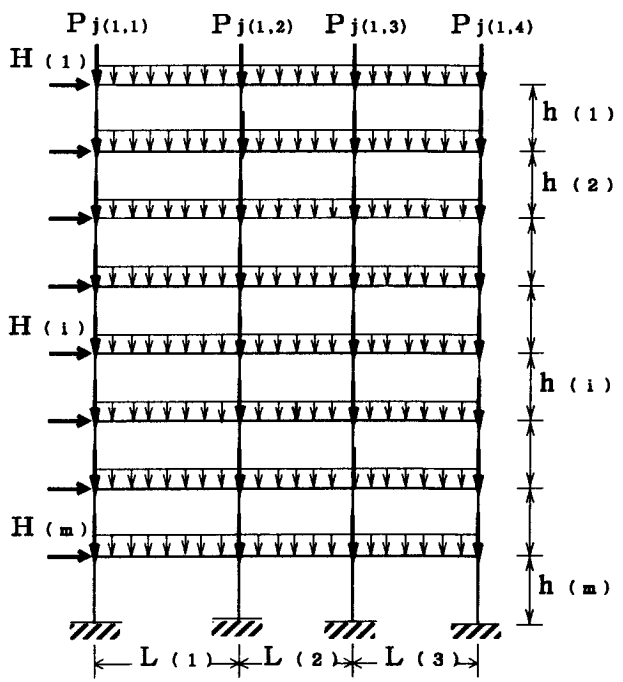

図 1 設計対象

\footnotetext{
*1 広島大学工学部 教授 Ph. D.

(テ 739 東広島市鏡山 1-4-1)

*2 三井建設 工修

*3 広島大学工学部 助教授・工博
}

\footnotetext{
*1 Professor, Hiroshima Univ., Ph. D.

1-4-1, Kagamiyama, Higashihirosima-shi)

*2 Mitsui Construction Co., M. Eng.
}

*3 Associate Professor, Hiroshima Univ., Dr. Eng 


\section{1 設部対象}

本報で取り扱う設計対象は図 1 に示す柱脚固定でブレースのな いm首 $\mathrm{n}$ スパンの鋼構造高層平面フレームである。柱部材は、市 販の角形鋼管か広幅 $\mathrm{H}$ 形鋼、はり部材は、市販の細幅 $\mathrm{H}$ 形鋼とす る。それらの形鋼の断面性能間の関係、すなわち、断面積と弾 ・ 塑性断面係数および断面二次モーメントは、マク口的に見て線形 関係にある ${ }^{8)}$ 。また、設計クライテリアは建築基準法に準拠する ものとする。したがって、あらかじめ D s 值は構造設計者の設計 方針に基ついて設定し、地震層せん断力分布は $\mathrm{A}_{\mathrm{i}}$ 分布を用いて 各層の必要保有水平耐力を求める。

\section{2 線形計画法(LP)を用いた最適塑性設計 ${ }^{32,4)}$}

ここでは、極限解析理論の下界定理を用いて平面骨組構造物の 最適塑性設計問題を線形計画問題の形で定式化する。

\section{1 领合条件及び降伏条件 ${ }^{8)}$}

平面骨粗構造物の釣合条件と降伏条件は、それぞれ次式(2.1),

\section{(2. 2)で表せる。}

$$
\begin{aligned}
& \left\{\mathrm{P}_{0}\right\}=[\mathrm{H}]\{\mathrm{r}\} \\
& \left\{\mathrm{r}^{\mathrm{L}}\right\} \leqq\{\mathrm{r}\} \leqq\left\{\mathrm{r}^{\mathrm{v}}\right\}
\end{aligned}
$$

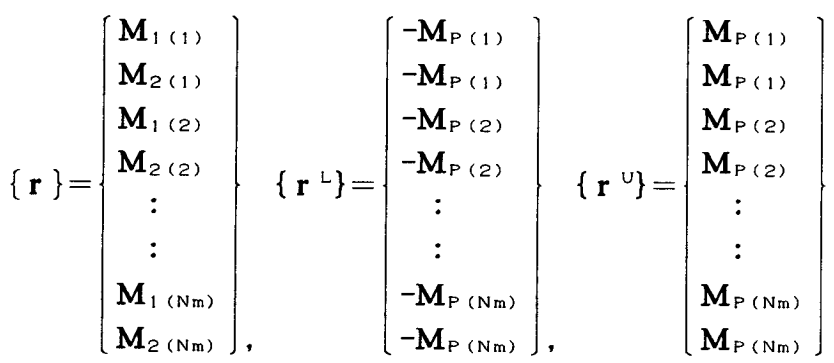

$\left\{P_{0}\right\}$ :柱梁節点における荷重ベクトル

$\{r\}:$ 各部材の部材力ベクトル

$[\mathrm{H}]$ : 荷重ベクトル $\{\mathrm{P}$ 。 $\}$ と部材力 $\{\mathrm{r}\}$ の釣り合いマトリックス

$M_{1}(i), M_{2}(i)$ : 部材 i の材端曲げモーメント

$M_{P}(i):$ 部材 i の全塑性モーメント

$\mathrm{N}_{\mathrm{m}}$ : 部材総数

\section{2 その他の制枋条件}

以上で示した一般的な制約条件に加えて設計解として実用的な 部材断面分布を得るために以下に示す条件を制約条件として付加 する。

柱の部材断面に対し

$M_{P(i+1, j)} \geqq M_{P(i, j)}$

$$
(\mathrm{i}=1,2, \ldots, \mathrm{m}-1)
$$

ただし、最上層を第 1 層、最下層を第m層とし、第 $\mathrm{i}$ 層の左か

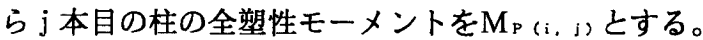

\section{3 目的関数}

全塑性モーメントと部材重量の間に線形関係が成立すると仮定 すると、最適塑性設計問題における目的関数 $\mathrm{f}$ は式(2.4)で定義 できる。

$$
f=\sum_{i=1}^{N m} L_{(i)} M_{P}(i)
$$

\section{4 最適設計問题の定式化}

最適塑性設計問題は、以下に示す形で定式化できる。

「制約条件 (2.1)，(2.2)，(2.4)式をすへて満足し、目的関数 f を 最小にする変数 $M_{1(i)}, M_{2}(i), M_{P}(i)(i=1,2, \ldots, N m)$ を求めよ。」 制約条件式(2.1), (2.2), (2.4)及び目的関数(2.5)は、変数 $M_{1}(\mathrm{i}), M_{2}(\mathrm{i}), M_{P}$ (i) を末知変数とする線形な方程式、不等式あ るいは関数である。従って、最適化手法として線形計画法が適用 できる。

\section{5 朝力・曲げ相関降伏条件を考慮した部材断面の選択}

2.4で定式化された最適塑性設計問題を線形計画法を用いて解 くことにより、指定した荷重に対して釣合条件を満足し、かつ目 的関数 $\mathrm{f}$ を最小にする材端モーメントが得られる。得られた材端 モーメント及びそれに鈞り合う軸力を用いて、(2.6a d)式の軸力 ・曲げ相関降伏条件 ${ }^{(0)}$ を満足し、かつ断面積が最小となる部材 断面を断面性能表より選択する。

$$
\begin{aligned}
& \frac{N_{(i)}}{N_{y}} \leqq \frac{A_{w}}{2 A} \text { の場合 } \\
& M_{1(i)} \leqq M_{P C}, \quad M_{2(i)} \leqq M_{P C} \\
& \frac{N_{(i)}}{N_{y}}>\frac{A_{w}}{2 A} \text { の場合 } \\
& M_{1(i)} \leqq \frac{2 A}{A+2 A_{F}}\left(1-\frac{N_{(i)}}{N_{y}}\right) M_{P C} \\
& M_{2(i)} \leqq \frac{2 A}{A+2 A_{F}}\left(1-\frac{N_{(i)}}{N_{y}}\right) M_{P C}
\end{aligned}
$$

$M_{1(i)}, M_{2(i)}$ :部材 i の材端曲げモーメント(2.4の設計問題の解)

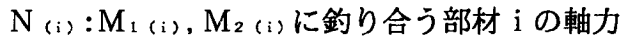

$\mathrm{N}_{\mathrm{y}}$ : 選択する部材断面の降伏軸力

$\mathrm{M}_{\mathrm{PC}}$ : 選択する部材断面の全塑性モーメント

$\mathrm{A}$ :選択する部材断面の断面積

$\mathrm{A}_{\text {w }}$ : 選択する部材断面のウェブ断面積

$A_{F}$ : 選択する部材断面のフランジ断面積

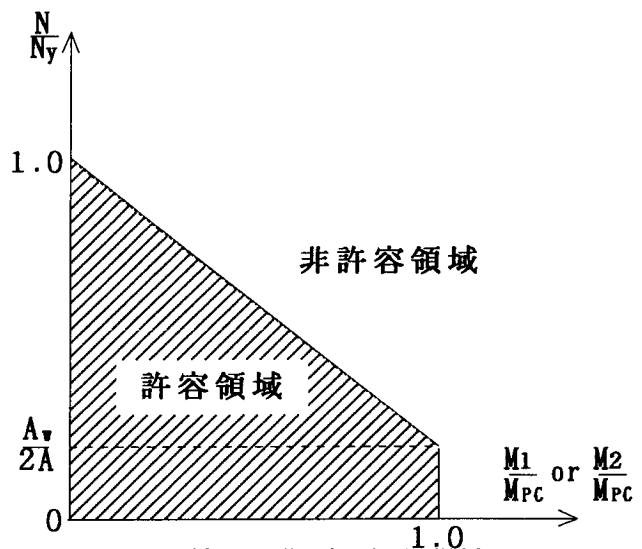

図 2 軸力と曲げの相関関係

L (i) : 部材 i の部材長 


\section{3 ラクラランジェ乗数法を用いた剛性設計法 ${ }^{12,2)}$}

一般に高層フレームの水平変位は骨組のせん断変形による水平 変位と柱の軸伸縮による曲げ変形などによる水平変位の総和とし て表される。本報では、骨粗のせん断変形による層間変位 $\delta_{\mathrm{t}}$ が 全層間変位 $\delta に$ 占める割合が大きいことに着目し、それにラグラ ンジェ乗数法を適用することにより、各層の必要岡性付加量を求 めることとした。ただし、ここでは一次設計の荷重に対する弾性 たわみを対象としている。

\section{1 变位解析}

たわみ角法の基本公式を用いて骨組のせん断変形による水平変 位 $\delta_{t}$ を近似的に求める。そのため各階の梁部材の曲け剛性につ いては最上層の上梁を除いて、図 3 に示すように各層の上下梁の 曲げ剛性を上下梁に均等に分割して考える。なお、I B (i，j)は、 第 $\mathrm{i}$ 層 $\mathrm{j}$ スパンの梁部材の断面二次モーメントを表し、 $I_{\mathrm{B}}^{\prime}(i, j)$

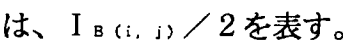

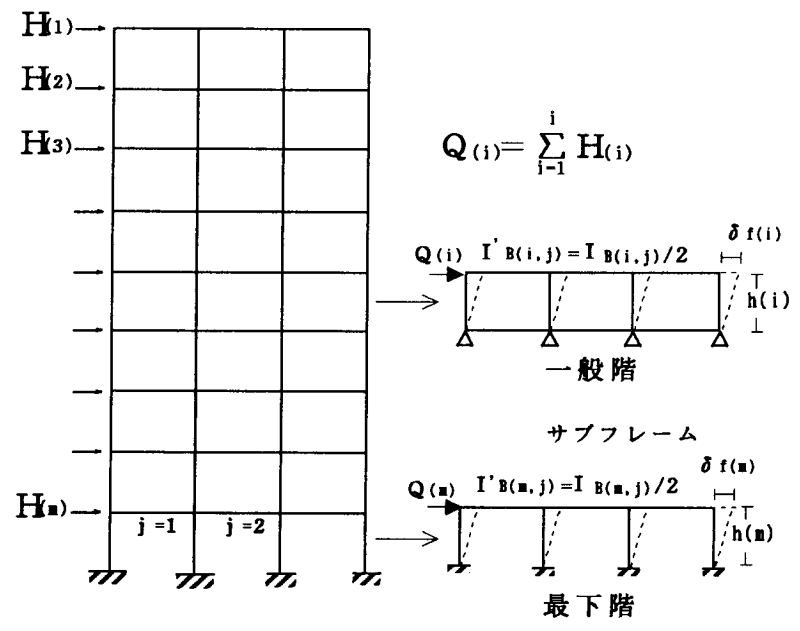

図 3 サブフレームの定義

\subsection{1 せん断変形による水平変位}

図3に示すサブフレームにおいてたわみ角法を適用すると各部 材の曲げ変形のみによって生じる骨組のせん断変形による水平変 位 $\delta$ :は式(3.1)、式(3.2)で定義される。ただし、ヤング係数を Eとする。

(A)一般陼における定式化

$$
\delta_{f(i)}=\frac{Q_{(i)}\left\{\mathbf{h}_{(i)}\right\}^{2}}{12 \mathrm{E}}\left[\frac{1}{\sum_{k=1}^{i+1} \sum_{j=1}^{n} K_{B}{ }^{\prime}(k, j)}+\frac{1}{\sum_{j=1}^{n+1} K_{C(i, j)}}\right]
$$

(B) 最下階における定式化

$$
\begin{aligned}
\delta_{1(m)} & =\frac{Q_{(m)}\left\{h_{(m)}\right\}^{2}}{12 E}\left[\frac{1}{\sum_{j=1}^{n+1} K_{c(m . j)}}\right. \\
& \left.+\frac{3}{\sum_{j=1}^{n+1} K_{C(m . j)}+12 \sum_{j=1}^{n} K_{B},(m . j)}\right]
\end{aligned}
$$

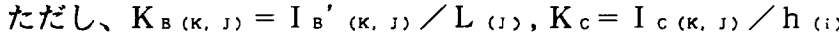
で、部材の剛度を表す。

以上の式を用いて階高 $3 \mathrm{~m}$ 、スパン間隔 $6 \mathrm{~m}$ 等スパン 15 層 3 スパンフレーム(表 $3 ， 4$ に部材を示す。)について計算した結果 を表1に示す。表中 $\delta$ は剛性マトリックス法によって得られた精

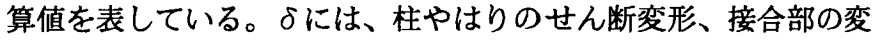
形などは考慮されていないが、表1より ${ }_{\mathrm{i}}$ がフレーム全体の水平 変位の主要な要因になっていることが確認できる。

表 1 水平変位 $(\mathrm{cm})$ （15層3スパンフレーム）

\begin{tabular}{|c|c|c|c|}
\hline 屏数 & $\delta_{\mathrm{f}}$ & $\delta_{\mathrm{e}}$ & $\delta$ \\
\hline 1 & 1.63 & 1.22 & 2.85 \\
\hline 2 & 2.47 & 1.20 & 3.67 \\
\hline 3 & 3.18 & 1.22 & 4.40 \\
\hline 4 & 3.82 & 1.22 & 5.04 \\
\hline 5 & 4.38 & 1.21 & 5.59 \\
\hline 6 & 4.89 & 1.19 & 6.08 \\
\hline 7 & 5.35 & 1.16 & 6.51 \\
\hline 8 & 5.77 & 1.11 & 6.88 \\
\hline 9 & 6.13 & 1.04 & 7.17 \\
\hline 10 & 6.45 & 0.96 & 7.41 \\
\hline 11 & 6.73 & 0.85 & 7.58 \\
\hline 12 & 6.97 & 0.73 & 7.70 \\
\hline 13 & 7.17 & 0.52 & 7.69 \\
\hline 14 & 7.27 & 0.05 & 7.32 \\
\hline 15 & 3.90 & 0.54 & 4.44 \\
\hline
\end{tabular}

$\delta_{\mathrm{f}}:$ 骨組のせん断変形による層間変位 $(\mathrm{cm})$ $\delta:$ 剛性マトリックス法によって得られた層間変位 $(\mathrm{cm})$ $\delta_{\mathrm{e}}: \delta_{\mathrm{t}}$ 以外の影響による層間変位 $\left(\delta_{\mathrm{e}}=\delta-\delta_{\mathrm{f}}\right)(\mathrm{cm})$ 首数:最上層より数えたレベルを表す。

\subsection{2 フレーム全体の水平変位}

多首フレームに対する水平変位は骨組のせん断変形による水平 変位や柱の軸伸縮による変位など様々な影響による水平変位の 総和として表される。

第 $\mathrm{i}$ 層に対して $\quad \delta_{(i)}=\delta_{t(i)}+\delta_{\mathrm{e}(\mathrm{i})}$

$\delta$ (i): 剛性マトリックス法によって得られた層間変位 $(\mathrm{cm})$ $\delta_{\mathrm{f}}(\mathrm{i}):$ 骨組のせん断変形による層間変位 $(\mathrm{cm})$ $\delta_{e}(\mathrm{i}): \delta_{\mathrm{f}}$ 以外の影響による層間変位 $(\mathrm{cm})$

\section{2 ラグランシェ乗数法による哃性設計解の定式化 ${ }^{1) ， 2)}$}

\subsection{1 㓮性設幛問題の定式化}

弾性応答に対する層間変位の制約条件は許容変位を $\delta_{\mathrm{P}}(\mathrm{i})$ として 式(3.4)で表される。

$$
\delta_{\mathrm{f}(\mathrm{i})}+\delta_{\mathrm{e}(\mathrm{i})}=\delta_{(\mathrm{i})} \leqq \delta_{\mathrm{P}(\mathrm{i})}
$$

式(3.4)を制約条件として、剛性設計問題は以下の最適設計問題 として定式化される。「制約条件式(3.5)、または式(3.6)を満足 し、かつ式(3.7)の目的関数 $\mathrm{f}$ を最小にする設計変数 $\mathrm{I}_{\mathrm{B}}$ 、 $\mathrm{I}$ ～ 決定する。」 
〈制粎条件式〉

(一籼陼)

$\phi_{(i)}=\frac{Q_{(i)}\left\{\mathbf{h}_{(i)}\right\}^{2}}{12 \mathbf{E}}\left[\frac{1}{\sum_{k=i}^{i+1} \sum_{j=1}^{n} \mathbf{K}_{B}^{\prime}(k, j)}+\frac{1}{\sum_{j=1}^{n+1} \mathbf{K}_{C(i, j)}}\right]$

$+\delta_{e(i)}-\delta_{P(1)} \leqq 0$

\section{(最下隌)}

$$
\begin{aligned}
& \phi_{(m)}=\frac{Q_{(m)}\left\{h_{(m)}\right\}^{2}}{12 \mathrm{E}}\left[\frac{1}{\sum_{j=1}^{n+1} K_{c(m, 1)}}\right. \\
& \left.+\frac{3}{\sum_{j=1}^{\mathrm{n}+1} \mathrm{~K}_{\mathrm{C}(m, 1)}+12 \sum_{j=1}^{\mathrm{n}} \mathrm{K}_{\mathrm{B}}^{\prime}(m, 1)}\right] \\
& +\delta_{e(m)}-\delta_{l(m)} \leqq 0
\end{aligned}
$$

\section{〈目的閏数〉}

$$
\begin{aligned}
f_{(i)}= & U \rho C_{B} \sum_{k=i}^{j+l} \sum_{j=1}^{n} I_{B}{ }^{\prime}(k, j) L_{(j)} \\
& +U \rho C_{C} \sum_{j=1}^{n+1} I_{C(i, j)} h_{(i)}+C
\end{aligned}
$$

$\rho$ :銅の比重, $\mathrm{U}$ :単位重量当たりの鉄骨価格, $\mathrm{h}$ (i) : $\mathrm{i}$ 層の階高

$\mathrm{C}, \mathrm{C}_{\mathrm{B}}, \mathrm{C}_{\mathrm{c}}$ : 部材断面の断面積之断面二次モーメントの線形関係 に示す定数 ${ }^{81}$

$\mathrm{I} B(\mathrm{i}, \mathrm{j}): \mathrm{i}$ 居 $\mathrm{j}$ スパンの梁の断面二次モーメント

$\mathrm{I} c(\mathrm{i}, \mathrm{j}): \mathrm{i}$ 届 $\mathrm{j}$ 列目の柱の断面二次モーメント

\subsection{2 ラダランシェ乗数法の適用}

弹性応答の首間変位が制限一杯之なるのは、式(3.5)、式(3.6) において等式の場合である。よって、最適化手法としてラグラン ジェ乗数法が適用でき、各首ごに以下の剛性設計解を得る。

〈一籼陼についての定式化〉

$$
\sum_{j=1}^{n+1} \mathbf{K}_{\mathrm{C}(i, j)}=\frac{\mathbf{Q}_{(i)}\left\{\mathbf{h}_{(i)}\right\}^{2}}{12 \mathrm{E}\left\{\boldsymbol{\delta}_{\mathrm{P}(i)}-\boldsymbol{\delta}_{e(i)}\right\}}\left[1+\sqrt{\frac{\mathrm{C}_{B}}{\mathrm{C}_{\mathrm{C}}}} \frac{\mathbf{L}_{(j)}}{\mathbf{h}_{(i)}}\right.
$$

$$
\sum_{k=i}^{i=1} \sum_{j=1}^{n} K_{B(k, j)}=\frac{Q_{(i)}\left\{h_{(i)}\right\}^{2}}{12 E\left\{\delta_{P(i)}-\delta_{e(i)}\right\}}\left[1+\sqrt{\frac{C_{C}}{C_{B}}} \frac{h_{(i)}}{L_{(j)}}\right]
$$

\section{〈最下堦についての定式化〉}

$$
\sum_{j=1}^{\mathrm{m}+1} \mathrm{~K}_{\mathrm{c}(\mathrm{m}, 1)}=\frac{\mathrm{Q}_{(\mathrm{m})}\left(\mathrm{h}_{(\mathrm{m})}\right)^{2}}{12 \mathrm{E}\left(\delta_{\mathrm{P}(\mathrm{m})}-\delta_{\mathrm{e}(\mathrm{m})}\right)} \frac{4+12 \mathrm{C}_{\mathrm{d}}}{1+12 \mathrm{C}_{\mathrm{d}}}
$$

$$
\left.\sum_{j=1}^{n} K_{B(m, j)} \frac{Q_{(m)}\left(h_{(m)}\right)^{2}}{12 E\left(\delta_{P(m)}-\delta_{e}(m)\right.}\right) \frac{C_{d}\left(4+12 C_{d}\right)}{1+12 C_{d}}
$$

ただし、

$$
C d=\left[\sqrt{\left\{\frac{36 C_{c}\left(h_{(m)}\right)^{2}}{C_{B}(L(j))^{2}}-3\right\}}-1\right] / 12
$$

\section{3 設社解の合成}

層間変位の制限に対する剛性設計解は式(3.8)〜式(3.12)で表 される。一方、塑性設計解は剛性設計解之は独立に求められてい る。従って、これらの結果をどのように合成して部材の剛性付加 量を決定するかが問題となる。この問題を明確にするために、図 4、5に各設計解の許容領域を図示する。式(3.5)及び式(3.6)で表 される 岡性設計の許容領域は図4で表せる。また、塑性設計の許容領域 は図5で表せる。最適点 $\mathrm{M}$ は 2 つの許容領域を淦足する領域に存 在し、塑性設計点 (点 $\mathrm{P}$ ) と剛性設計点 (点D) の位置関係によ って起こりうる状態は以下の 4 caseに限定される。

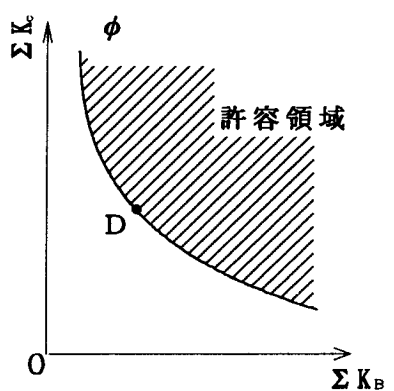

図 4 剛性設計解の許容領域

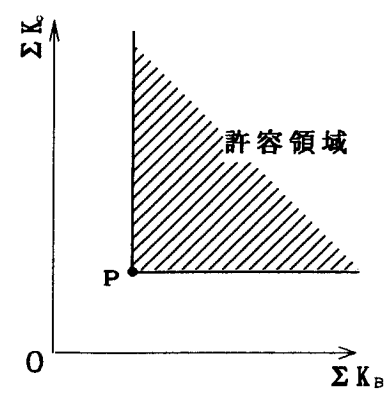

図 5 塑性設計解の許容領域 (Case 1) 柱、梁网性付加（図6）

$\Sigma K_{\mathrm{C}} 、 \Sigma \mathrm{K}_{\mathrm{B}}$ に対してともに犅性設計解が塑性設計解を上回って いる場合、最適点Mは剛性設計解の点Dで与えられる。この場合、 柱梁の両方を剛性付加しなければならず、図6に示す $\triangle K_{\mathrm{B}} 、 \triangle \mathrm{K}$ ‘が必要とされる剛性付加量となる。

\section{〈Case 2〉梁のみ州性付加（因7）}

柱部材の岡度和 $\Sigma \mathrm{K}_{\mathrm{c}}$ は剛性設計解より塑性設計解の方が大きく、 梁部材の剛度和 $\Sigma \mathrm{K}_{\mathrm{B}}$ は塑性設計解より剛性設計解の方が大きい 場合に相当する。この場合には柱部材には、剛性付加の必要はな いが梁部材は剛性付加が必要となり、その剛性付加量は図7に示 す $\triangle K_{\mathrm{B}}$ に等しい。 また、最適点 $M$ における梁部材の剛度和 $\Sigma$ $K_{\mathrm{B}}$ は式(3.5)または式(3.6)で表される中に塑性設計で得られた 柱部材の岡度和 $\Sigma \mathrm{K}_{\mathrm{CP}}$ を代入することにより与えられる。

\section{(Case 3) 柱のみ㣚性付加（図8）}

梁部材の剛度和 $\Sigma K_{\mathrm{B}}$ は剛性設計解より塑性設計解の方が大き く、柱部材の剛度和 $\Sigma \mathrm{K}$ 。は塑性設計解より剛性設計解の方が大 きい場合に相当する。この場合には梁部材は剛性付加の必要はな いが柱部材は剛性付加が必要となり、その剛性付加量は図8に示

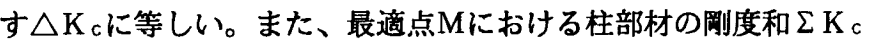
мは式(3.5)または式(3.6)で表される中に塑性設計で得られた梁

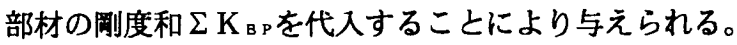




\section{(Case 4) 滆性付加の必要なし（図9）}

$\Sigma K_{c} 、 \Sigma K_{\mathrm{B}}$ に対してともに塑性設計解が岡性設計解を上回っ ている場合、最適点 $\mathrm{M}$ は塑性設計解の点 $\mathrm{P}$ で与えられる。この場 合、剛性付加する必要は無く、塑性設計解が最終設計解となる。
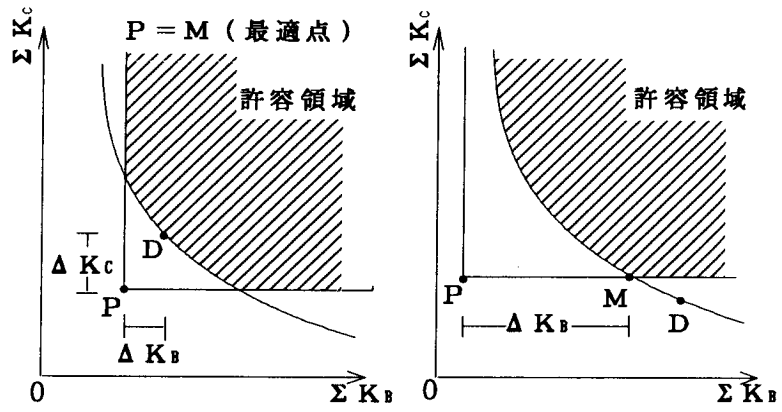

図6 Case 1 柱はり剛性付加 図7 Case 2 はりのみ剛性付加
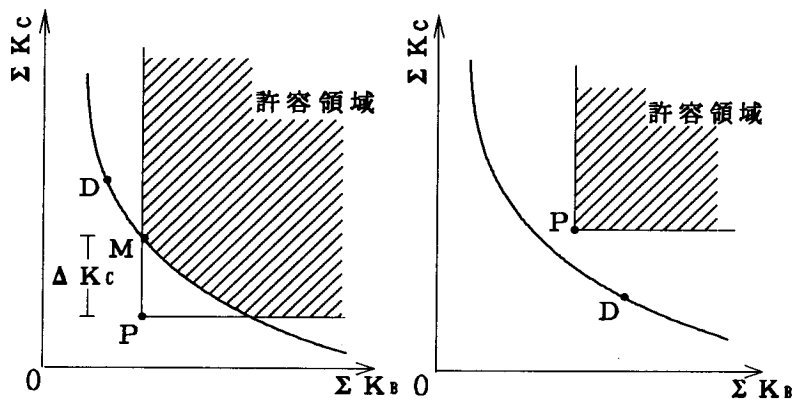

図8 Case 3 柱のみ剛性付加 図9 Case 4 剛性付加なし

3.4 刚性設計法のフローチャート

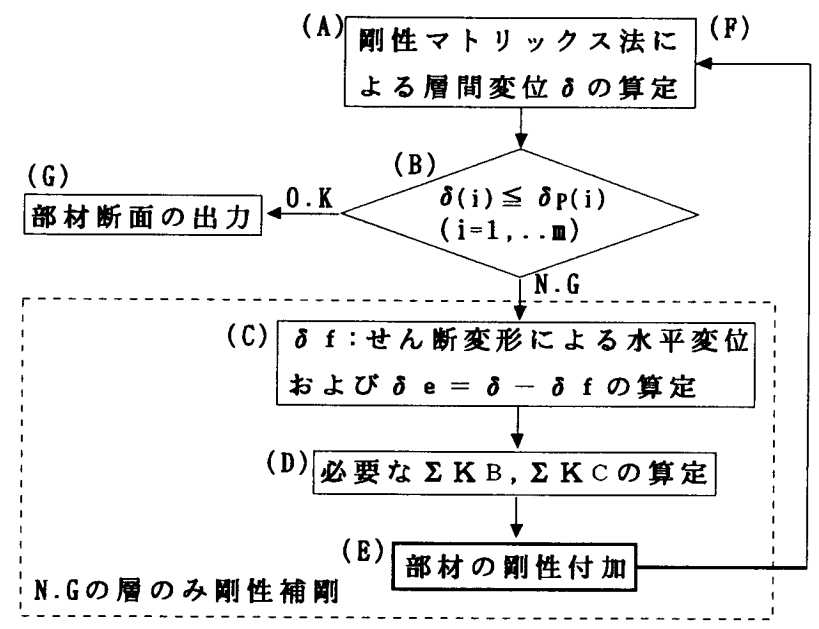

図 10 剛性設計法のフローチャート

剛性設計法は以下の手順に従って行うものとする。剛性設計法 のフローチャートを図10に示す。(A) 塑性設計法で得られた部材 断面を用いて岡性マトリックス法により各層の層間変位を求める。 (B)全層 $(i=1, \ldots \mathrm{m})$ の層間変位について許容層間変位 $\delta_{\mathrm{P}}$ を越えて いないかを検討する。許容層間変位 $\delta \mathrm{p}$ を越えている層について は(C) (E)のプロセスを行う。(C)各首のせん断変形による層間変

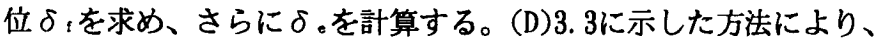

各層の柱、はり各々の補岡量 $\Delta \mathrm{K}_{\mathrm{c}}, \Delta \mathrm{K}_{\mathrm{B}}$ を求める。( $\left.\mathrm{E}\right)$ 各首の柱、 はりを補剛して新たな部材断面を求める。(F)新たな部材断面を 用いて、再び网性マトリックス法により層間変位を求める。(G) すへての層で許容変位を満足していれぱ、岡性設計を完了する。 満足していない層に対しては、(C)〜 (F)を絽り返す。

\section{4 断面算定例と他法との比較}

線形計画法を用いた最適塑性設計法を行い、得られた設計解に 対して、剛性マトリックス法を用いて弾性解析を行う。すへての 部材について許容応力度の検討を行い、必要ならば部材断面の修 正を行う。ラグランジェ乗数法を用いた岡性設計法により各首の 柱はりの剛性付加量を求め、部材断面を修正し、最終的な部材断 面を得る。設計のブロックチャートを図11に示す。

\section{1 断面算定例}

本報で提案した弾塑性設計法の設計適用例を示す。設計対象は 15 階建(ただし、5 階建、10階建については紙面の都合上銅 材総重量と計算時間のみ示した。）、階高はすへて $3 \mathrm{~m}$ 、柱間隔 はすへて $6 \mathrm{~m}$ 、設計用床荷重を表2、同一断面の指定については 図12、図13に示す。柱部材には角形鋼管、梁部材には細幅 $\mathrm{H}$ 形銅 を使用する。適用結果として設計解を表3、表4に示す。設計解よ り計算された鋼材棇重量を表5、演算時間 (CPU TIME, 広島大学情 報処理センター計算サーバ、CONVEX C3240) を表6に示す。

\section{2 弾性応答と塑性涌力を同時に考盧した最適弾塑性設计法 ( S 設計法)との比較}

弾性応答之塑性耐力を同時に考虑した最適弾塑性設計法 ${ }^{6), 6) ~}$ （Ｓ設計法)を用いて断面算定を行った。ただし、設計条件につい ては式(2.4)で定義される条件及び離散解を求めている以外は同 じとする。表5より鋼材総重量を比較すると本設計法でも十分経 斎的な総重量を得ているもの亡考えられる。さらに、表5より首 数が増加するにつれ演算時間が急激に増加する S 設計法に比し、 本設計法は短い演算時間で設計を終えていることが確認される。

\section{5 まとめ}

現行の建築基準法のルート 3 に準拠した鋼構造高首フレームの 部材断面の算定に対し、本報では、線形計画法を用いた最適塑性 設計法と剛性マトリックス法による弾性解析を基にした弾性設計 法とさらにラグランジェ乗数法を用いた最適化手法による剛性設 計法を段階的に適用することにより、効率よく部材断面の算定が できることを示した。そして、本報による断面算定結果と弾性応 答と塑性酎力を同時に考虑した最適弾性・塑性設計法 ${ }^{5}$ による結 果を比較し、全鎆材重量について実用的に許容できる範囲内に入 っていることを示した。

\section{鼣辞}

本研究を行うにあたり、広島大学工学部助手の澤田樹一郎氏に協 力を得ました。ここに厚く感謝の意を表します。 


\section{考文献}

1) Y.Nakamura,'Plastic Design Method of Multi-story Planar Frames with Deflection Constraints, 'Doctoral Thesis in partial fulfillment of the requirements for the Doctor of Philosophy Degree in Dept. of C.E. at M.I.T., R68-12,1968

2）田中尚, 中村雄治,「建築構造物の自動設計と最適設計」, 培 風館, pp. 139 170, 1973

3）土木学会, 「構造システムの最適化〜理論と応用〜」, pp. 196〜206, 1988年

4) R. H. Gallagher, 0. C. Zienkiewicz 共編、川井忠彦、户川隼人 監訳、「最適構造設計 基礎と応用」, pp247～262, 培風館

5）澤田樹一郎, 中村雄治, 松尾彰「反復線形計画法を用いた平面 ラーメンの最適弾性・塑性設計法」, 日本建築学会構造系論文報 告集 第485号，1996年7月

6）沢田樹一郎, 中村雄治, 松尾彰: 平面ラーメンの最適弾性・塑性 設計に関する研究, 日本建築学会大会学術講演梗概集 (北海道) C-1, pp. 149 150, 1995年

7）大上元一, 中村雄治, 松尾彰, 「水平耐力配分法を用いた高層 平面フレームの弾性・塑性設計法」，日本建築学会大会梗概集
(北海道)C-1, pp. 151 152, 1995年

8）大上元一, 中村雄治, 松尾彰, 「高酋平面フレームの弾塑性設 計法に関する研究」，日本建築学会中国・九州支部研究報告第 10 号, pp. 593 596, 1996年3月

9）青山博之, 上村智彦,「マトリックス法による構造解析」, 培風 館, pp. 283 314, 1988年

10）日本建築学会,「鋼構造設計規準」, 1973年

11）日本建築学会,「鋼構造塑性設計指針」，1975年

[1996 年 6 月 17 日原稿受理 1996 年 9 月 10 日採用決定］ 表2 設計用床荷重

\begin{tabular}{|c|c|c|}
\hline & \multicolumn{2}{|l|}{ 設計用床荷重 $\left(\mathrm{kg} / \mathrm{m}^{2}\right)$} \\
\hline \multirow{2}{*}{ 一般階 } & 鉛直荷重 & 700 \\
& 水平荷重 & 700 \\
\hline \multirow{2}{*}{ 最上階 } & 鉛直荷重 & 800 \\
& 水平荷重 & 800 \\
\hline
\end{tabular}

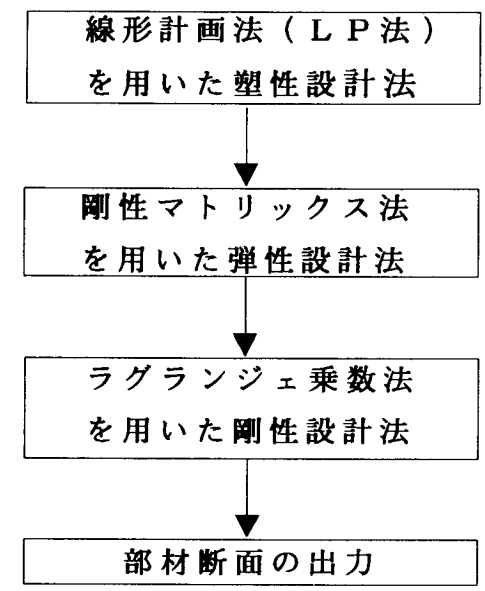

図11 弾塑性設計法のブロックチャート

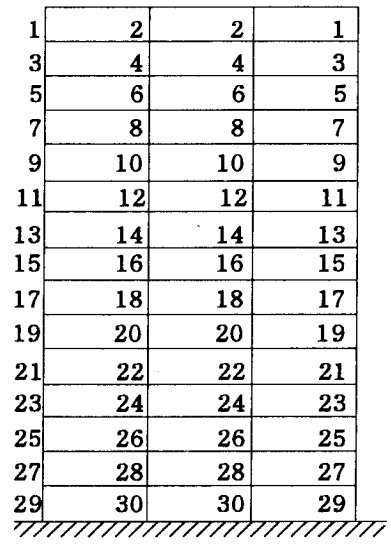

図12 柱部材の部材番号

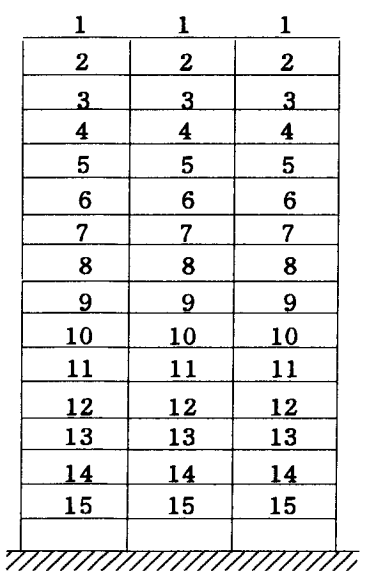

図13 梁部材の部材番号

表5 鋼材絵重量 $(t)$

\begin{tabular}{|r|c|c|}
\hline & 本設計法 & S 設計法 \\
\hline 層数 & 棇重量 & 総重量 \\
\hline 5 & 15.7 & 15.5 \\
\hline 10 & 46.8 & 45.2 \\
\hline 15 & 79.1 & 77.1 \\
\hline
\end{tabular}

表6 計算時間(CPU TINE)（SEC)

\begin{tabular}{|c|c|c|}
\hline & 本設計法 & S 設計法 \\
\hline 層数 & 計算時間 & 計算時間 \\
\hline 5 & 2.31 & 1.63 \\
\hline 10 & 3.53 & 11.4 \\
\hline 15 & 4.74 & 80.9 \\
\hline
\end{tabular}

